\title{
Concept Mapping: An Innovative Tool to Teach Critical Community Health Nursing Using the Example of Population Health Promotion
}

\author{
Dr. Aliyah Dosani ${ }^{1,2}$, Dr. Candace Lind ${ }^{3}$, Sylvia Loewen ${ }^{3}$ \\ ${ }^{1}$ School of Nursing and Midwifery, Faculty of Health, Community and Education, Mount Royal University \\ ${ }^{2}$ Department of Community Health Sciences, Cumming School of Medicine, University of Calgary \\ ${ }^{3}$ Faculty of Nursing, University of Calgary
}

Cite as: Dosani, A., Lind, C. \& Loewen, S. (2019). Concept Mapping: An Innovative Tool to Teach Critical Community Health Nursing Using the Example of Population Health Promotion. Witness: The Canadian Journal of Critical Nursing Discourse, 1(2), 30-48. https://doi.org/10.25071/2291-5796.29

\begin{abstract}
Introduction: Concept mapping is a tool that is used to visualize complex factors and the links between them. While concept mapping is represented in community health practice and research literature, we found little information about using concept mapping in community health nursing education. Background: We developed an innovative concept map assignment to assist students to visualize complex inter-related factors and begin thinking about appropriate and relevant nursing interventions, using the Population Health Promotion Model (PHPM). Discussion: Concept maps enhanced the quality of meaningful teaching and learning at the university level, acting as both a learning and assessment strategy. Students exhibited critical thinking and drew conclusions that involved larger systemic issues such as social justice and health equity. Conclusion: Concept mapping is a powerful tool that facilitates and assesses authentic student learning. The concept map assignment was also an effective tool to help students grasp and apply the PHPM.
\end{abstract}

Key Words: Critical thinking, social justice, concept maps, community health nursing

\section{Introduction}

Community health nurses (CHNs) work in a variety of settings including where people live, work, worship, learn, and play. While CHNs serve in various roles such as public health nursing, occupational health nursing, home health nursing, street nursing, and military nursing, to name a few (Phillips \& Schofield, 2020), they all help decrease inequities in health status by addressing the social determinants of health. A recent report by the Public Health Agency of Canada (2018) indicates that in the Canadian context people who are racialized, Indigenous, gender variant, or otherwise left with precarious access to the social determinants of health have the poorest health outcomes and quality of life. Compounding social issues including poverty, homelessness, violence, and food insecurity produce both physiological and psychological stress that introduce various health risks across the lifespan (Garg, Sandel, Dworkin, Kahn, \& Zuckerman, 2012). We wanted to explore the complexity of these issues with our nursing students so they would understand how (whether as future community health nurses or acute care nurses) they could implement relevant interventions that would help to decrease inequities in health status. We developed a concept map

assignment that would help our students learn to analyze the various complexities that individuals, families, communities, and populations experience that have an impact on their health.

\section{Background Literature on Concept Mapping}

Concept mapping was initially developed in the 1960s by educational psychologists who emphasized the need to explore new concepts through building on prior knowledge (Ausubel, 1968). In nursing education, concept maps have been used primarily as an acute care tool for students to communicate their understanding of the complex relationship between numerous concepts and diagnoses on a single piece of paper, and as an 


\section{See it. Speak it. Write it. Change it.}

alternative to developing nursing care plans to guide patient care (All, Huycke \& Fisher, 2003; Harrison \& Gibbons, 2013; Kaddoura, VanDyke, Cheng, \& Shea-Foisy, 2016). There are many ways to construct concept maps. The most common types of concept maps are those that (a) demonstrate cause and effect, (b) show a main idea and its details developed hierarchically (Novak \& Gowan, 1984), and (c) are thematic and represent clusters of networks (Ruiz-Primo \& Shavelson, 1996). Concept maps have been defined as a tool to arrange key concepts, creating a picture that shows the links between them (All \& Havens, 1997). These maps are a means of expressing relationships, interpretations, and understandings of an issue (Hinck et al., 2006). Concept maps assist students to link theory to practice (Daley, 1996), capture and promote students' critical thinking (All \& Huycke, 2007; Higgins \& Reid, 2017; Lee et al., 2012), encourage active engagement with course material thereby promoting meaningful learning, and retaining new knowledge (Harrison \& Gibbons, 2013; Hunter Revell, 2012). Through their meta-analysis of the literature, Nesbit and Adesope (2006) discovered concept mapping is more effective for knowledge retention and transfer than traditional teaching and learning activities. However, in their systematic review and meta-analysis Yue, Zhang, Zhang, $\&$ Jin (2017) question the impact of the use of concept mapping on developing the critical thinking skills of nurses. In this article, we will demonstrate how the use of concept mapping can be used to develop not only critical thinking skills of community health nursing students, but we will establish how teaching students to take a critical stance can inform future community health nursing practice. We align our definition of critical with that of McGibbon and Lukeman (2019) who highlight that, while rooted in critical social theory, taking critical perspectives "center on questions about the genesis and maintenance of societal power hierarchies, including questions about access to knowledge production and the goods and services of society. Within this framework, issues of self, identity, power, economy, culture, and social justice are explicitly analyzed" (p. 4).

We reviewed the literature, searching for an evaluative tool for a community health nursing theory class that would engage student nurses in the critical thinking necessary to understand the complex interrelated concepts (such as the social determinants of health) that influence the health of populations. We found concept mapping is represented mainly in the community health practice and research literature (Aarons, Wells, Zagursky, Fettes, \& Palinkas, 2009; Burke et al., 2005; Schell et al., 2013; Vaughn, Jones, Booth, \& Burke, 2017). In community practice settings, pictorial representations are used during strategic planning to link high level concepts and issues; and demonstrate their inter-relationships. Developing visual representations is a dynamic process that encourages practice teams to interact with each other and the drawings, facilitating creativity and collaboration in the planning process.

From the education literature, Hinck et al. (2006) evaluated the effectiveness of concept mapping as a learning strategy for 23 students in a community-based mental health clinical course. They found the students' care plans were more comprehensive than traditional care plans when they diagrammed main concepts and the interrelationship between concepts. In addition, students gained a greater understanding of the complexity of clients' situations and why their problems were so difficult to resolve. Daley, Morgan, and Black Beman (2016) identified that while concept mapping has been used in nursing education for the past two decades, there are gaps in the literature related to applying concept map scoring formulas, and, creating concept map-centered learning environments. There is currently no literature available that describes the use of concept mapping to evaluate student learning in a community health nursing theory course, or that used the population health promotion model (PHPM) (Flynn, 1999). We begin to fill this gap by offering an innovative assignment for consideration. We focus on how we sought to improve the quality of teaching and learning in a both second- and third-year community health theory course, using a concept map assignment employing the PHPM.

\section{Concept mapping to teach the PHPM and to Incorporate a Critical Lens}

A broad perspective assists community health nurses to understand how multiple factors and their interaction influence a client's health, which then guides the development of specific nursing interventions to promote that client's health. Community health nursing practice often requires nurses to look at the "bigger picture" using the PHPM where the client (who could be defined as an individual, family, community, structure/system, or society) is viewed from a broad perspective using the social determinants of health (Flynn, 1999). The PHPM is visually represented as a cube with one side listing the social determinants of health, another side listing levels of action (the above multiple "client" levels), and the third side listing action strategies arising from the Ottawa Charter for Health Promotion (Flynn, 1999). Potential action strategies include: (a) develop personal skills, (b) create supportive environments, (c) build healthy public policy, (d) strengthen community action, and (e) reorient health services. The base of the PHPM includes its evidence-informed decision-making foundation.

We believed using concept mapping with the PHPM was worth exploring as a learning and evaluative tool for students to (a) demonstrate their understanding of the complex, intertwined factors underlying peoples' health, (b) show how the determinants of health influence population health outcomes, and (c) identify relevant interventions to improve the health of populations. Students selected a complex community level issue (such as childhood obesity or violence in families) and then formulated a title question to guide their literature search and development of the concept map. Students included three components in their title: the population, the identified health priority or issue, and the focus chosen (root cause, risk factors, or protective factors). Table 1 gives examples of topic choices student may select from. We intentionally selected topics that were currently relevant and would help to highlight inequities in health. Students were asked to select a population group choice that piqued their curiosity and they were genuinely interested in learning more about. We believed that giving students control of their work in this way would increase their 


\section{See it. Speak it. Write it. Change it.}

level of engagement. We also added an option for a student to propose an alternate population rendered vulnerable by social and structural inequities they were interested in exploring further.
Table 1.0 Topics and Population Group Choices for Students

\begin{tabular}{|c|c|}
\hline General Topic & Population Group Choices \\
\hline \multirow[t]{4}{*}{ Poverty and Homelessness } & Families Living in Poverty \\
\hline & Adults Experiencing Homelessness \\
\hline & Refugee Families Displaced by War \\
\hline & Adolescents Experiencing Homelessness \\
\hline \multirow[t]{4}{*}{ Violence and Abuse } & Children Experiencing Family Violence \\
\hline & People Experiencing Intimate Partner Violence \\
\hline & Older Adults Experiencing Financial Abuse \\
\hline & People who have Survived Violent Crimes \\
\hline \multirow[t]{4}{*}{ Sexuality } & Adolescents Expecting Children \\
\hline & People who Engage in Sex Work \\
\hline & People who Experience Human Trafficking \\
\hline & People who Identify as LGTBQAI2S+ \\
\hline \multirow[t]{4}{*}{ Substance Use } & People Who Use Injection Drugs \\
\hline & Adolescents who Smoke Tobacco or Cannabis \\
\hline & Seniors who Abuse Alcohol \\
\hline & Professionals who Use Illicit Substances \\
\hline \multirow[t]{4}{*}{ Obesity and Overweight } & Children who are Overweight or Obese \\
\hline & Adolescents Who are Overweight or Obese \\
\hline & Adults who are Overweight or Obese \\
\hline & Food Supply or Policy that Impact Food Choice \\
\hline \multirow[t]{4}{*}{ Social Injustice } & Indigenous People's Access to Safe Drinking Water \\
\hline & Access to Affordable Housing for All \\
\hline & Older Adults who are Isolated \\
\hline & People living with Different Abilities \\
\hline
\end{tabular}

An example of a title question is "What are the risk factors related to the social determinants of health for Indigenous people's access to safe drinking water?" In this example, the focus is Indigenous people with the health issue of inadequate access to safe drinking water and the approach is to examine the risk factors that contribute to this access issue (Figure 1). Including these three elements in the question was critical in providing a clear focus and direction for the students as they developed their maps.

Students used either a legal sized ( $81 \frac{1}{2} \times 14$ inches) sheet of paper or larger poster paper ( $24 \times 36$ inches), to incorporate between 20 and 25 concepts (choosing one of: root causes, risk factors, or protective factors related to the health issue) as their concept map building blocks. All concepts were referenced using a superscript number linked to a number on their reference list. Furthermore, students linked each concept to one or more of the social determinants of health, with at least eight represented on their map. Initially, the social determinants of health choices students could use included: income and social status, work and working conditions, social support networks, personal coping skills, healthy child development, physical environments, social environments, education, genetic endowment, health services, culture, and gender (Flynn, 1999).

While the students initially could choose determinants of health listed in the PHPM-income and social status, work and working conditions, social support networks, personal coping skills, healthy child development, physical environments, social environments, education, genetic endowment, health services, culture, and gender (Flynn, 1999) — we noted that this list of health determinants used neutral verbiage and did not always serve to draw students' attention to 


\section{See it. Speak it. Write it. Change it.}

various health equity and social justice issues inherent in community health nursing practice. We wanted students to be clear about the differences between inequity and inequality and the language we chose to use for the social determinants of health had a big role to play with this. Indeed, McGibbon and Lukeman (2019) emphasize language as a key site of power. Specifically, we defined inequity as the differences in health that are unfair and unjust (World Health Organization, 2008). For example, the PHPM uses the neutral term social environments whereas

Mikkonen \& Raphael (2010) suggested altered determinant of health language that shifted away from a neutral focus to pinpoint what the inequities are that determine poorer health outcomes for particular populations. Using the term social exclusion raises questions that the term social environments does not, such as: Who is excluded and why? While the more accurate term to use would be social inclusion (as this is the determinant of the best health outcomes), using the term social exclusion raises additional questions including: by whom are people excluded? Is this exclusion overt or covert? How is exclusion justified? How often are people excluded? How does social exclusion impact health? Raising these types of questions would have implications for what students identified as appropriate community health nursing interventions. As such, in later iterations of this assignment, we searched the literature and began to use language that placed importance on health equity and social justice, including sourcing literature on Indigenous/Aboriginal peoples' determinants of health (Benach et al., 2014; Canadian Nurses Association, 2007; Canadian Public Health Association, 2015; Castañeda et al., 2015; Chircop, 2020; Greenwood, de Leeuw, Lindsay, \& Reading, 2015; Health Canada; 2013; Martin \& Evans, 2015; Martyn, 2004; Mikkonen \& Raphael, 2010; Paradies et al., 2015; Pearce \& Davey Smith, 2003; Public Health Agency of Canada, 2018; Reading, \& Wein, 2013; World Health Organization, 2011). The revised list of determinants of health that students could choose from is presented below:

- Income and Income Distribution/Poverty

- Education/Literacy/Education Systems

- Unemployment and Job Security/Precarious Employment

- Employment and Working Conditions

- Early Childhood Development (early life)/Childhood Experiences/Healthy Child Development

- $\quad$ Food Insecurity

- Housing

- Physical Environment (including natural and built environments, community infrastructure, resources, and capacities)/Environmental Stewardship

- Migration/Dislocation

- Immigration

- Cultural Continuity (the degree of social and cultural cohesion within a community)

- Relationships with Territory/Land

- Social Environment

- Politics/War/Conflict

- Colonization

- Biology and Genetic Endowment

- Social Exclusion

- Social Status

- Social Safety (Support) Networks/Social Capital

- Access to Health Services/Health Service Systems

- Personal Health Practices and Coping Skills/Healthy Behaviours
- Self-Reliance and Self-Determination

- Aboriginal/Indigenous Status

- Gender

- Culture

- Race/Racism (social stratification along racial lines with consequent hierarchical distribution of resources, power, freedom, and control)

- Having different abilities

Each main concept could also potentially be broken down into sub-concepts. We defined sub-concepts to be elements or items within a main concept, with links portrayed in a hierarchical manner. For example, one concept for inadequate access to safe water in Indigenous communities could be colonialism and assimilation and a sub-concept could be loss of spiritual connection (Figure 1). Another example of a concept could be fragmentation in governance and a sub-concept could be inequitable policies (Figure 1)

Students identified specific community health nursing interventions either from the literature or what they thought would be an appropriate intervention using their critical thinking for a number of the concepts on their map (Figures $2 a-5 b$ ). Furthermore, students were instructed to link these specific community health nursing interventions to one or more of the five action strategies from the PHPM, as appropriate. Through this process, students were able to demonstrate not only their critical thinking skills, but also their theoretical understanding of community health nursing concepts. To complete their assignment, their chosen interventions were linked to one of the five levels of action in the PHPM.

In addition, students wrote a short 800-word discussion paper to expand upon two concepts arising from their map, using the remaining components of the PHPM (see marking rubric in Appendix). Instructions included (1) discuss how the concept related to their selected social determinant(s) of health, (2) expand on a specific nursing intervention, (3) specify and explain how the nursing intervention is relevant to one of the five health promotion action strategies in the PHPM, (4) identify and discuss which level of action their chosen health promotion strategy best aligns with, (5) identify their values and assumptions that led to the nursing interventions they recommended, and (6) identify the underlying evidence-base that justified their decisions about what nursing interventions were relevant and why specific recommendations were made. While the initial word count limitation was partially imposed to manage the marking workload in very large theory classes, we saw the value that the self-reflection brought to the development of critical nursing practice in novice community health nursing students. Nursing students were able to identify personal biases and assumptions they held and how this impacted their decisions for community health nursing interventions. McGibbon, Mulaudzi, Didham, Barton, \& Sochan (2014) identify that it is necessary for nurses to engage in introspection along with dialogue and action, to re-examine preconceived ideas about nursing and to recognize positions of privilege and Western and personal worldviews as major influences in nursing practice. Furthermore, we found some nursing students required significant guidance, despite in-class discussions. For example, a number of nursing students would arrange appointments to ask if they were "doing it right?". Perhaps some nursing students were seeking permission to take a critical stance. Taking a critical stance and questioning the status quo may be frowned upon in more dominant nursing courses that focus on medical and surgical nursing or a biomedical understanding of nursing practice. As such, our future plans are to expand on the self-reflection component of the assignment so that students can demonstrate how identifying their underlying values, attitudes, and assumptions enable them to 
practice community health nursing from a more critical lens. There is still a need to

openings to question "why" do we do practice in certain ways and who may be shift nursing practice from focusing on "how" to do practice, to one that creates harmed in the process?

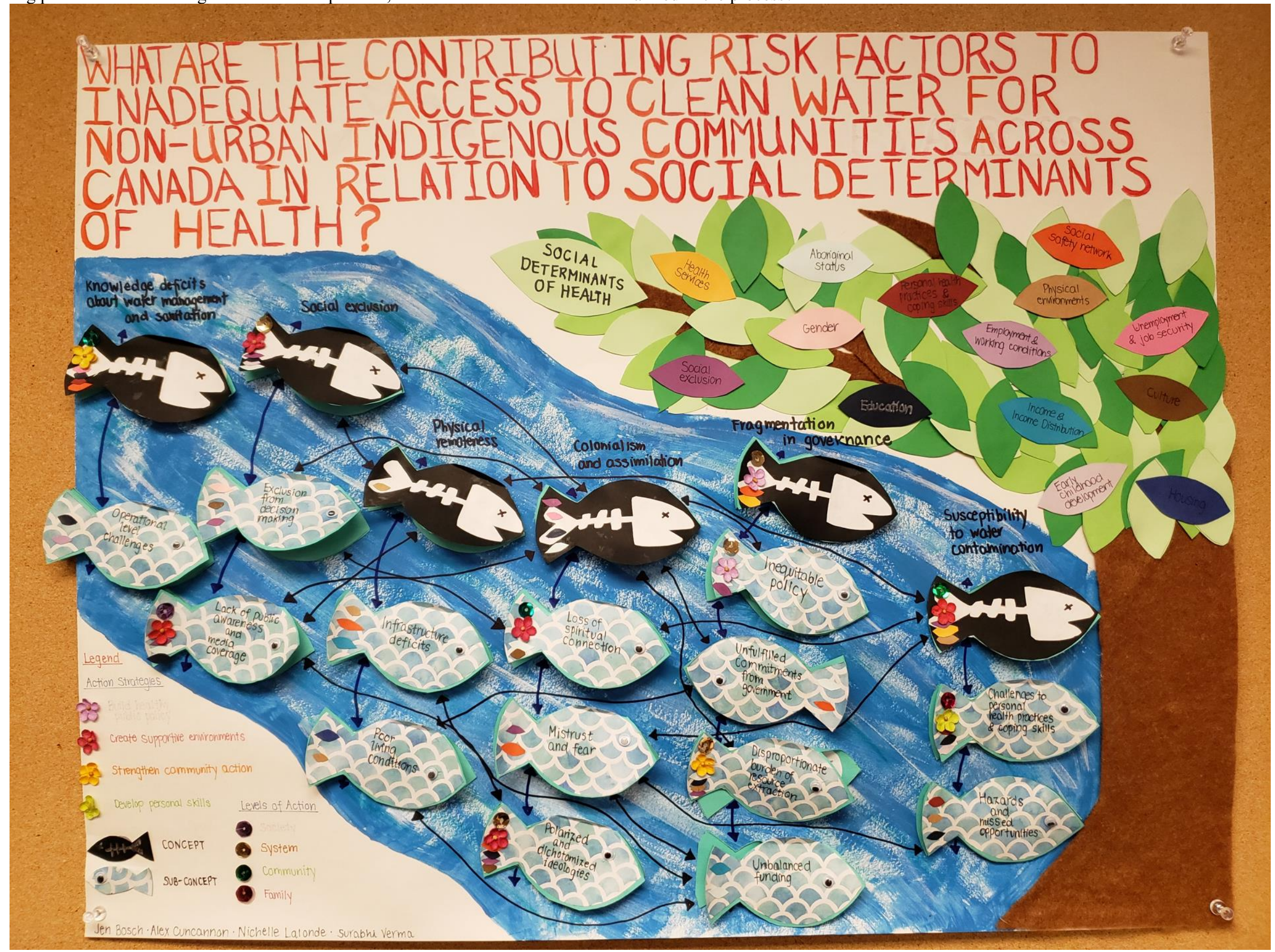

Figure 1. Example of a Concept Map Relating to the Issue of Access to Safe Drinking Water and Indigenous Communities Across Canada 
The Canadian Journal of Critical Nursing Discourse

See it. Speak it. Write it. Change it.

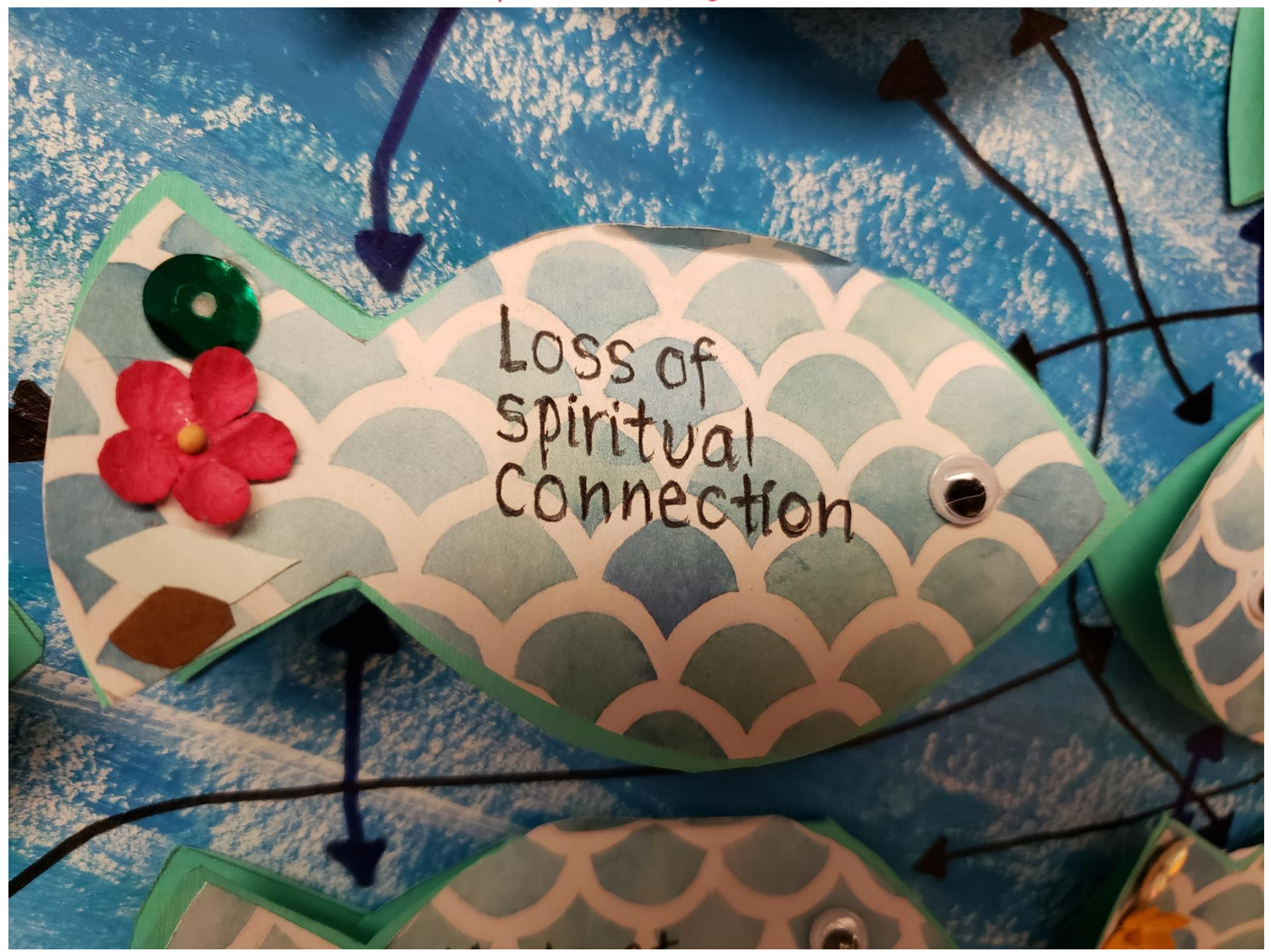

Figure 2a. Narrowing in on the Sub-Concept of Loss of Spriritual Connection 
The Canadian Journal of Critical Nursing Discourse See it. Speak it. Write it. Change it.

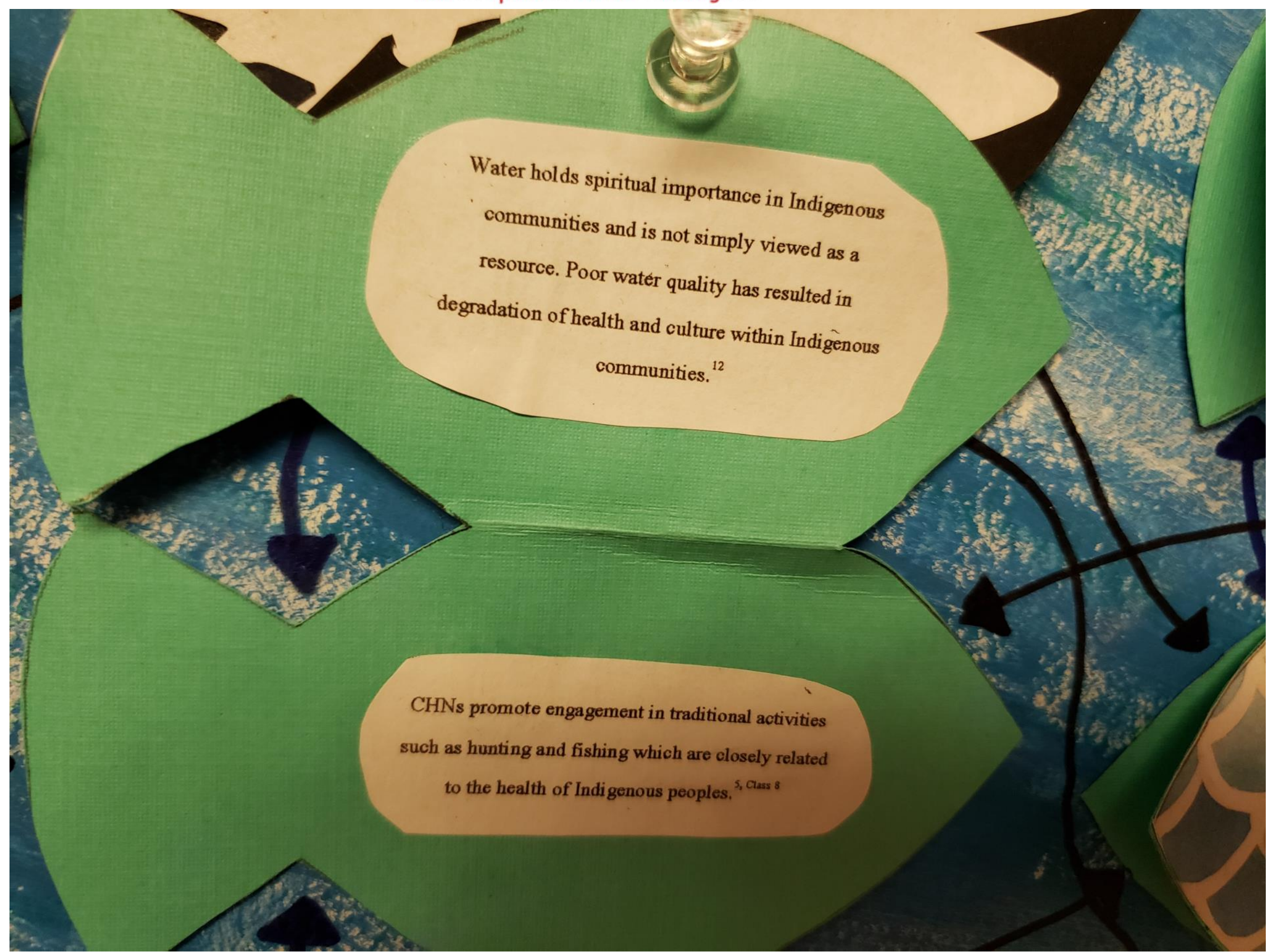

Figure 2b. Explanation of how Loss of Spiritual Connection is a Risk Factor for Inadequate access to Safe Drinking Water and CHN

Interventions 
The Canadian Journal of Critical Nursing Discourse

See it. Speak it. Write it. Change it.

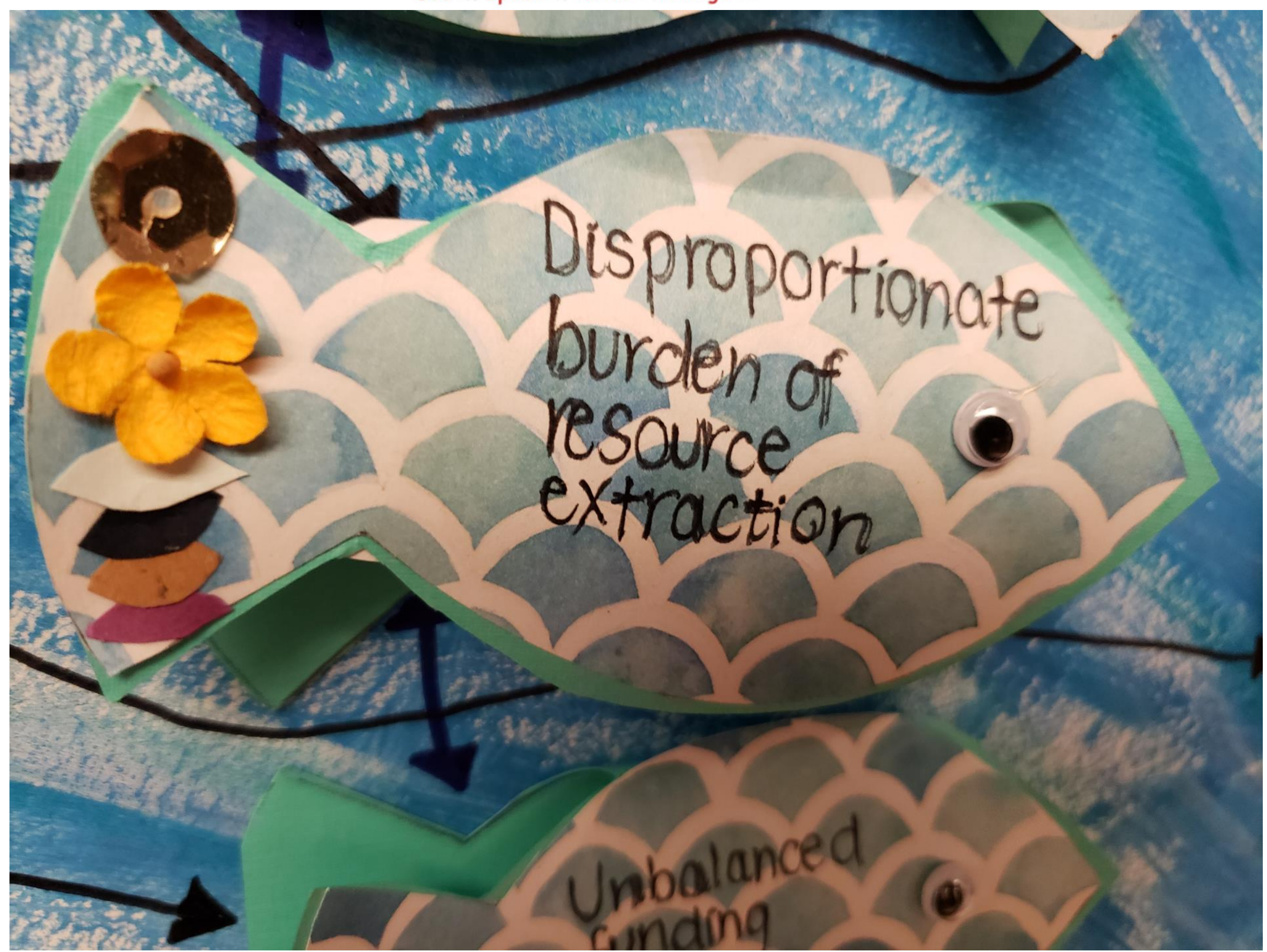

Figure 3a. Narrowing in on the Sub-Concept of Disproportionate Burden of Resource Extraction 
The Canadian Journal of Critical Nursing Discourse

See it. Speak it. Write it. Change it.

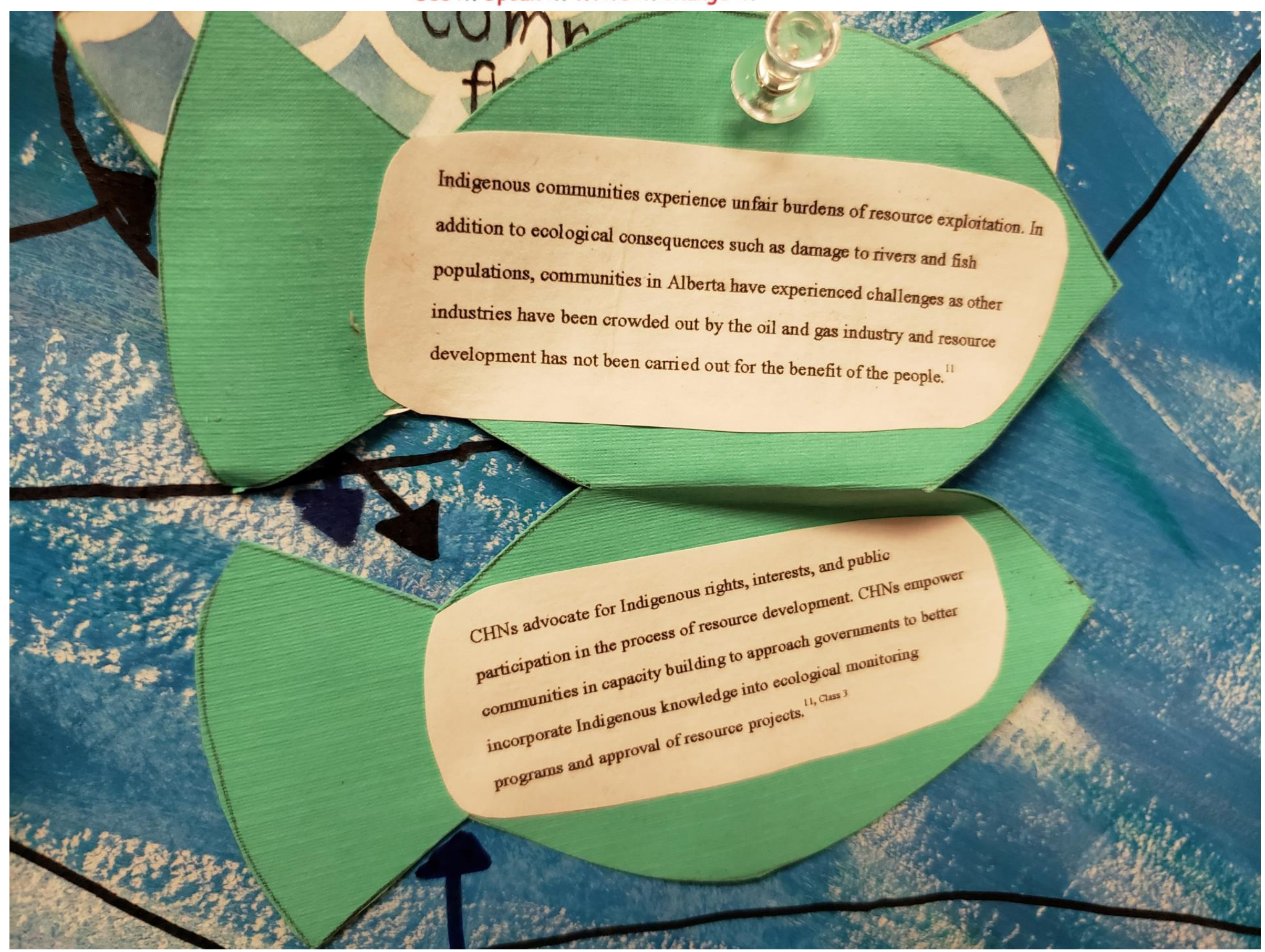

Figure 3b. Explanation of how Disproportionate Burden of Resource Extraction is a Risk Factor for Inadequate access to Safe

Drinking Water and CHN Interventions 
The Canadian Journal of Critical Nursing Discourse

See it. Speak it. Write it. Change it.

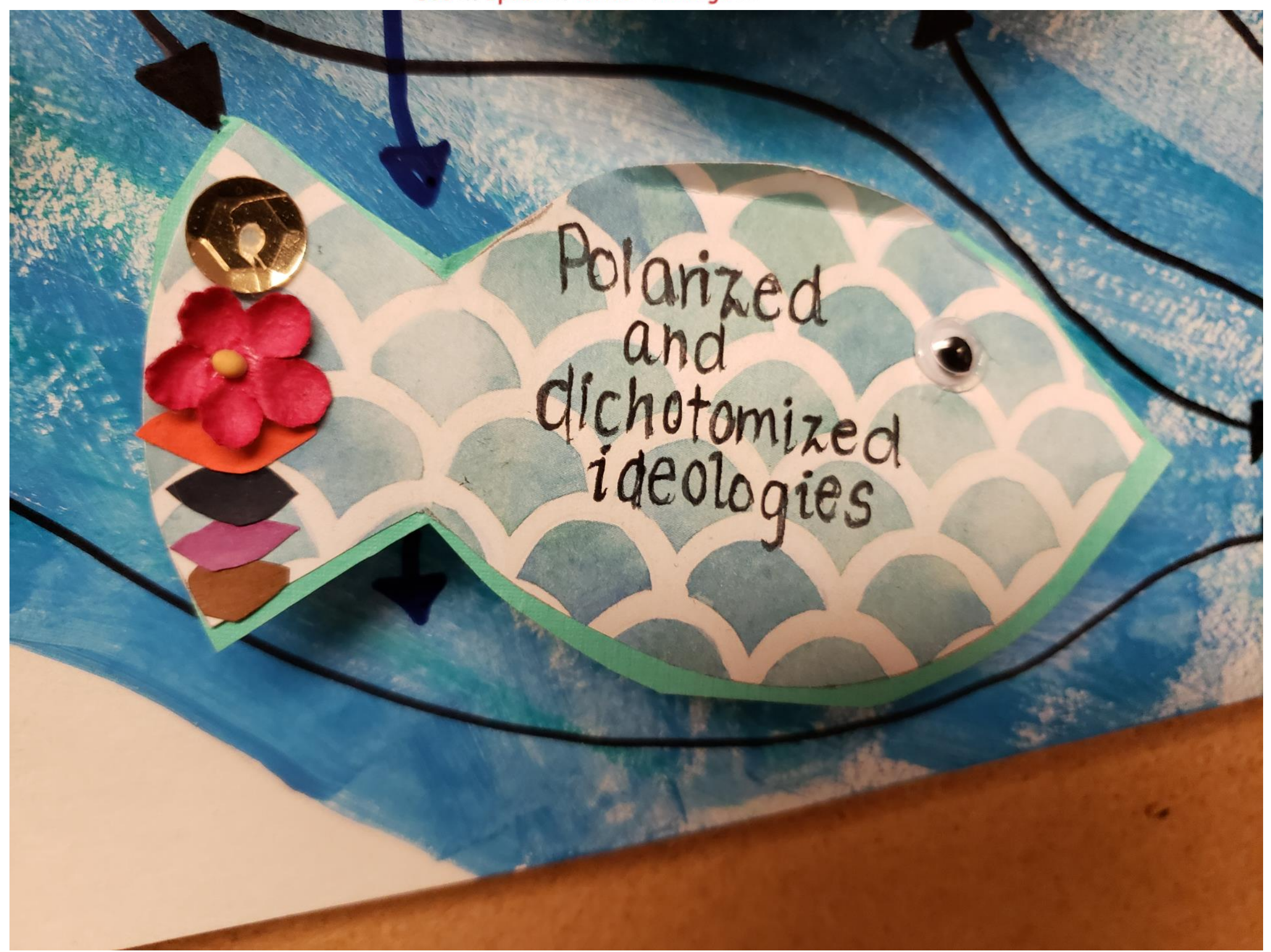

Figure 4a. Narrowing in on the Sub-Concept of Polarized and Dichotomized Ideologies 
The Canadian Journal of Critical Nursing Discourse See it. Speak it. Write it. Change it.

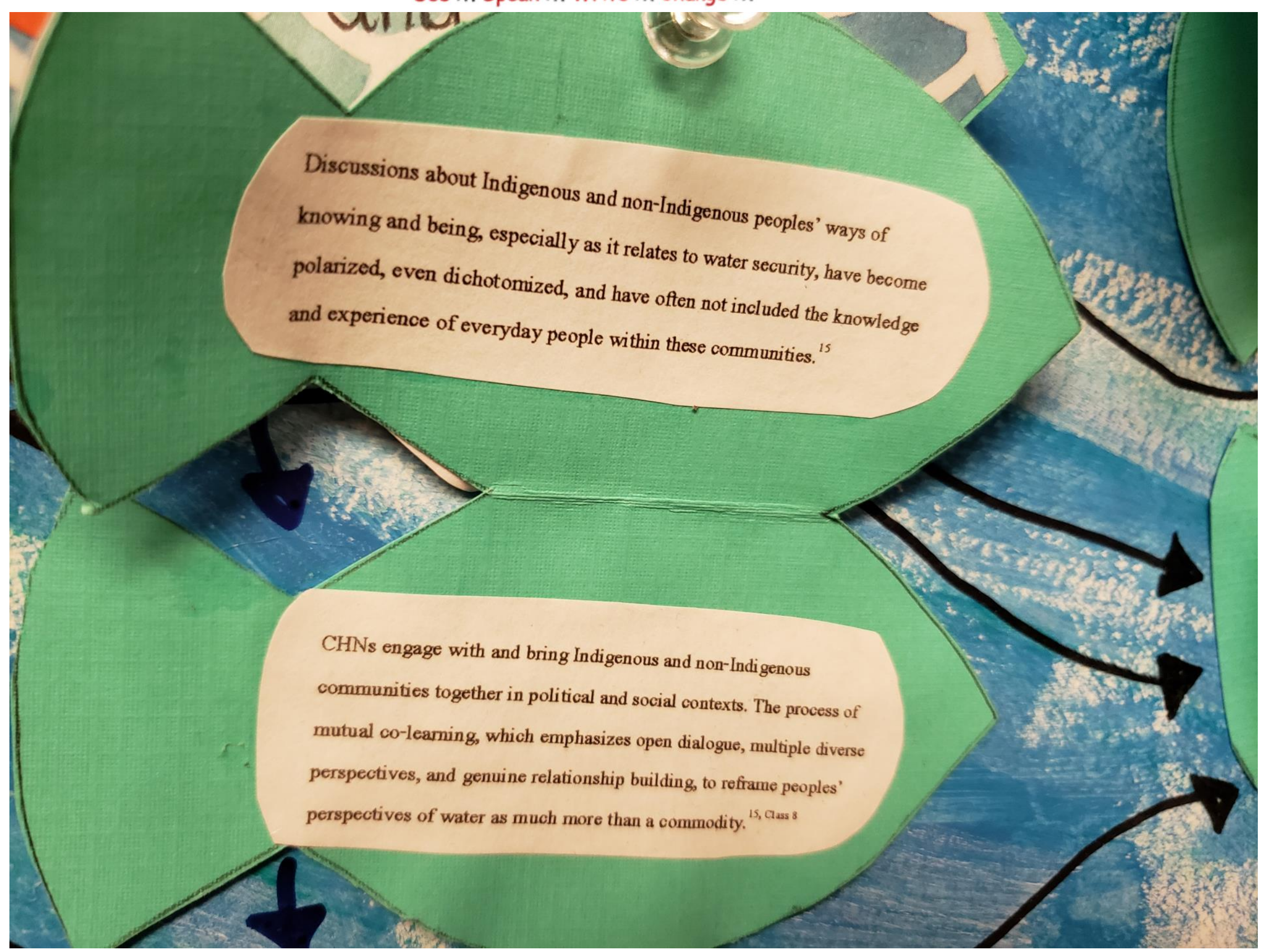

Figure 4b. Explanation of how Polarized and Dichotomized Ideologies is a Risk Factor for Inadequate access to Safe Drinking Water and CHN Interventions 
The Canadian Journal of Critical Nursing Discourse

See it. Speak it. Write it. Change it.

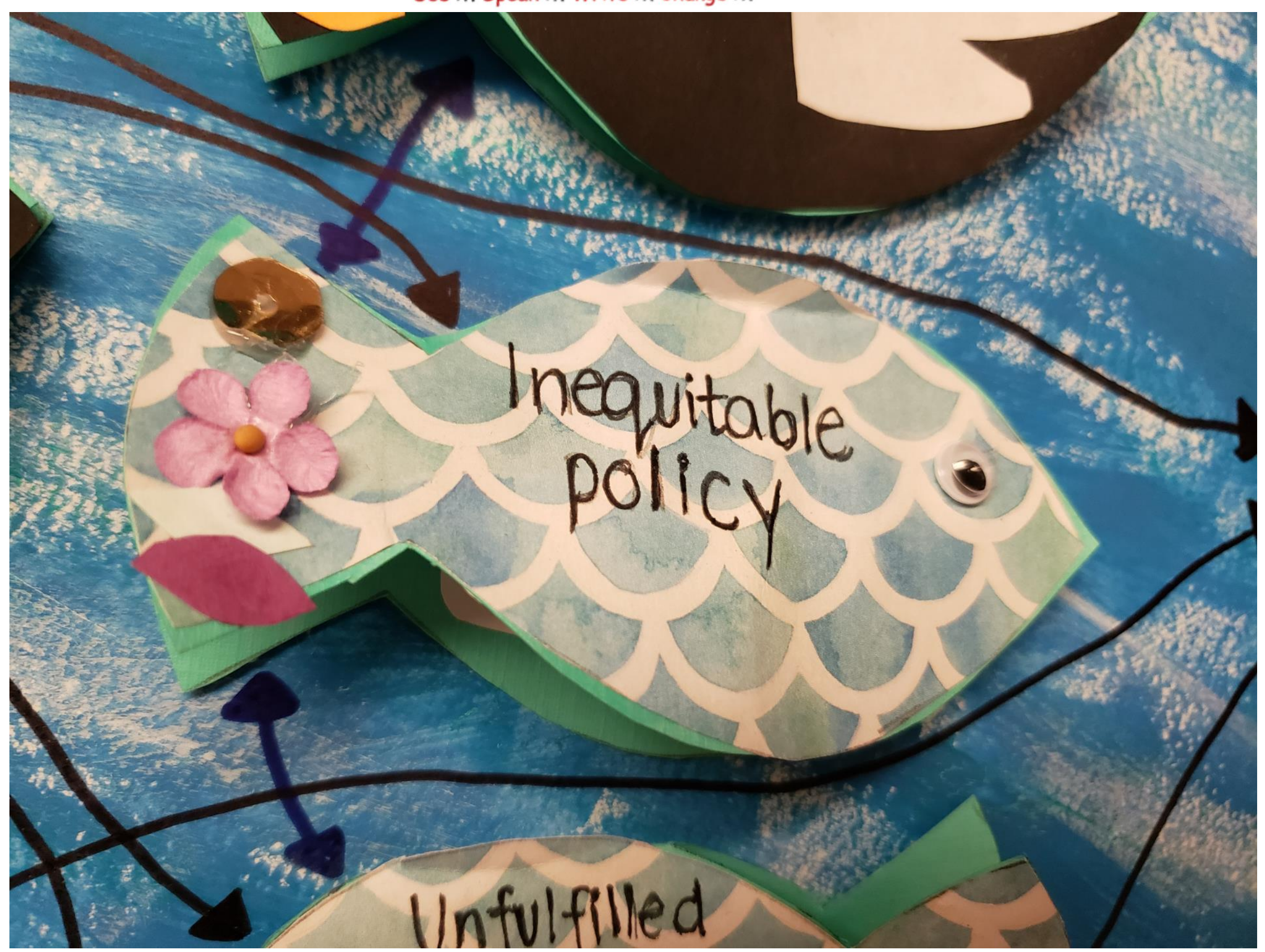

Figure 5a. Narrowing in on the Sub-Concept of Inequitable Policy 
See it. Speak it. Write it. Change it.

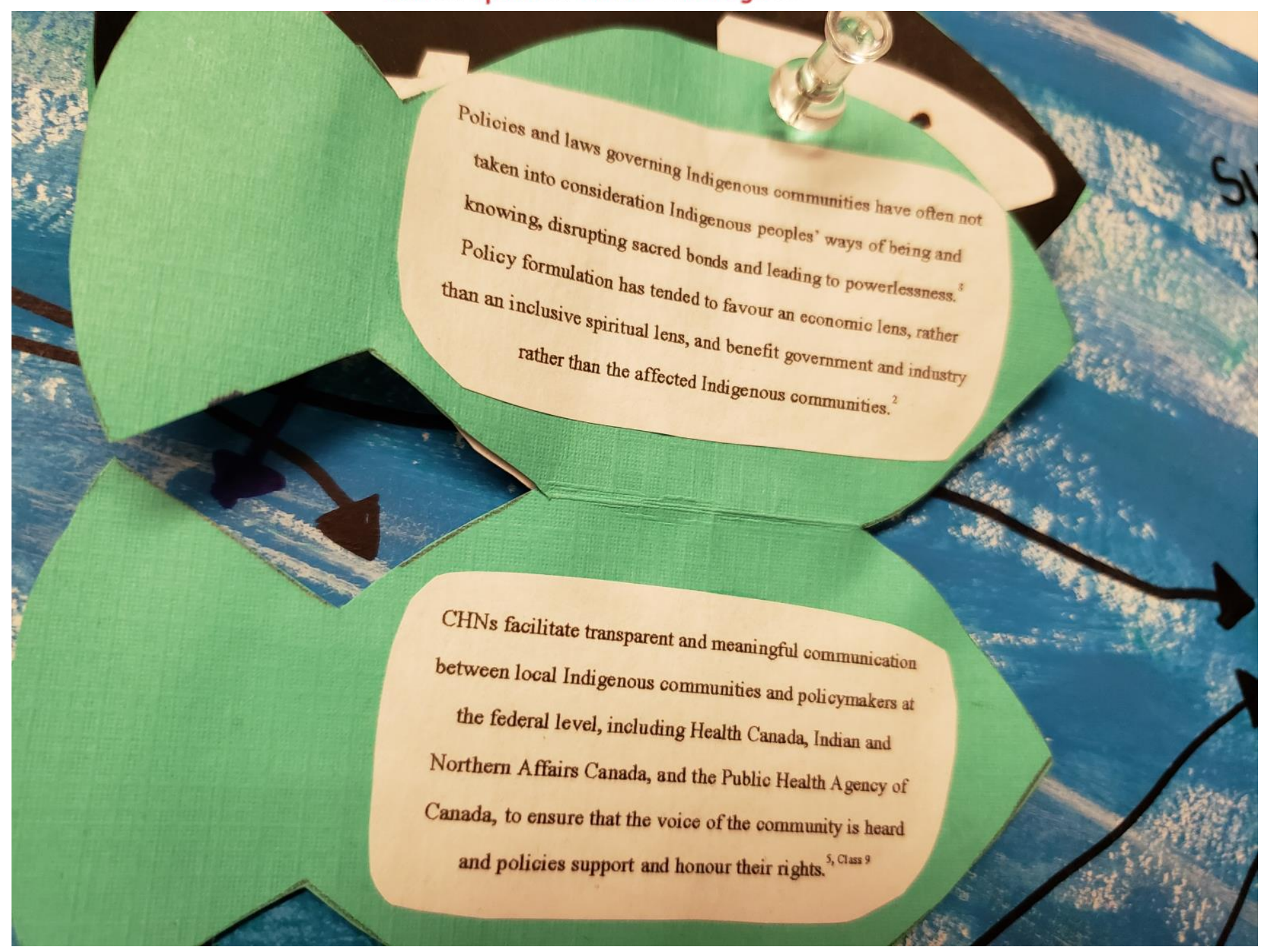

Figure 5b. Explanation of how Inequitable Policy is a Risk Factor for Inadequate access to Safe Drinking Water and CHN Interventions

\section{Implications for Teaching Critical Community Health Theory}

Rather than a more traditional learning approach of memorizing facts, concept maps assist students to relate new knowledge to prior understanding and identify how multiple parts connect with one another to produce a cohesive whole (Hinck et al., 2006). The use of concept maps contributes to the quality of meaningful teaching and learning at the university level, acting as both a learning and assessment strategy (Hay, Kinchin \& Lygo-Baker, 2008). In addition, Hay et al. (2008) indicate that concept maps allow for meaningful learning to be visible to both the student and instructor, as we also discovered.
Daley and Torre (2010) suggested concept mapping achieves success in four main ways, by (a) promoting meaningful learning in terms of critical thinking and problem solving; (b) providing an additional resource for learning by enabling students to develop a system of thinking, pattern recognition, and integration of knowledge; (c) enabling instructors to provide feedback to students, by identifying student misunderstandings (e.g., students often confuse social support network with social environment); and (d) conducting assessment of learning and performance in terms of critical thinking and reasoning processes. We found all of this occurred with our concept map assignment. Specifically, with respect to students' critical thinking and reasoning processes, when we identified a mis-match between the issue and specific community health nursing intervention or how the specific community health nursing intervention 


\section{See it. Speak it. Write it. Change it.}

aligned with the action strategies represented on the PHPM, this then gave us the opportunity to identify and correct student misunderstandings of key course concepts. We found the concept map assignment engages the learner with the content in an effective manner.

Health equity and social justice are central to community health nursing (Dosani, Etowa, \& van Daalen-Smith, 2020). Through the concept map assignment, we observed how students were able to exhibit critical thinking and drew conclusions that involved larger systemic issues such as social justice and equity. Through the process of working on the assignment, they realized the etiology of health issues were complex, hence requiring multilevel intervention strategies to address root causes of population health issues. Overall, students felt the concept map illustrated the connections between the social determinants of health in a visual manner as they could draw lines on their maps showing the complex connections between and within concepts and the related determinants of health. Hence, students came to "understand how the various structural determinants of health contribute to health equity gaps for individuals, families, communities, and populations" (Dosani et al., 2020, p. 605). The concept map assignment also helped students understand how to engage in various community health nursing practice situations in an anticipatory way. For further depth, some students were able to conduct an intersectional analysis of the topic they had explored. According to Bowleg (2012), intersectionality is a theoretical framework that suggests that the multiples cross-sections of various social categories experienced at the individual or micro level (including race, gender, sexual diversity, and socioeconomic status) are related to or arise from systems of power, privilege, and oppression at the macro socio-structural level (including racism, sexism, heterosexism, and classism). We observed that the concept map assignments helped students showcase the complexity of the interrelated community health nursing concepts more clearly than would have been achieved solely in a written paper. The concept map brought community health nursing practice to life for them.

The concept map assignment allowed students to convey a multitude of ideas that may have taken 20 or more pages to explain in words. A criticism from some was that it took more time to develop a one-page concept map than they thought it would have taken to write a longer paper. However, because the students were meant to select two concepts from their map to explore in depth in their 800-word discussion paper, the assignment also allowed for students to practice how to convey their learning in a succinct and concise manner. We feel giving students the opportunity to think about how best to frame their interventions succinctly can also add value in the form of teaching them how to frame messages for clients as well. However, we found that conciseness in self-expression for the assignment was a challenge for some students.

The opportunity for creativity in organizing their ideas was refreshing for some, especially for those who called themselves visual learners. The visual representation of a map clearly showed the intricacies and intertwined relationships between the course concepts, leading to a greater depth of appreciation for the complex and intersectoral collaboration required to address community health issues. Nurses' roles in policy-making and the necessity of having an influence on larger systems levels to create health became clearer. We noticed students were beginning to understand the importance of roles in policy-making, advocacy, and activism in nursing. The assignment offered a trade-off in terms of learning. Solely having a written paper might allow for more reflection. However, the concept map assignment offered new thinking or a different way of thinking which presented possibilities for deeper learning, hence bringing to the forefront the value of taking a critical community health nursing approach.

In one iteration of the assignment, students were offered class time to showcase and speak about their concept maps. We found that through their presentations students were able to discuss the inadequate social policies and programs, imbalanced and often prejudiced economic arrangements, and corrupt politics that lead to health inequities (WHO, 2008; Marmot \& Bell, 2011). Furthermore, students were beginning to identify entry points for $\mathrm{CHNs}$ to effectively navigate complex policy environments, beginning from various sociopolitical processes that have implications for their practice at various levels, ranging from individual to systems levels. In these classroom presentations and accompanying discussions, we also recognized that students were beginning to demonstrate numerous pathways for cultivating and enacting critical perspectives such as acting in solidarity, working at the grassroots, exploring alternatives, and developing political literacy (McGibbon \& Lukeman, 2019). Nursing students voiced that they saw the value in understanding that nursing practice must expand into arenas where decisions are made. Finding ways to speak at decisionmaking tables is a significant part of nursing practice.

Through the concept maps, students demonstrated how they understood and were able to apply the concepts of community health nursing and develop effective strategies for interventions that reflected taking a critical stance. This assignment provided an opportunity to show creativity through use of art in designing their map. In addition, for students whom English was not their first language, the opportunity to portray their learning through a different assignment format led to positive changes in their overall community health nursing course grade. An unanticipated positive outcome for the instructors was that it took less time to mark than a longer written paper.

There are a number of limitations to acknowledge. Firstly, because this work to date has not included a research component, we do not know if the assignment was equally effective in illuminating structural/systemic root causes for students who chose to focus on risk factors or protective factors, and those who chose to focus on root causes. Secondly, while some students did identify dominant discourses and oppressive practices, as well as nurses' potential role in challenging inequities that result from these discourses and practices, we cannot conclude that the assignment was effective in getting all students to analyze these complexities. Because this 


\section{See it. Speak it. Write it. Change it.}

assignment is currently implemented in beginning level community health nursing courses at the undergraduate level, we suggest that examining more complex issues may be better situated in a senior level community health nursing course. Thirdly, some interventions identified by students did not address structural/systemic root causes of the population health issues being explored such as institutional racism, social exclusion, and intergenerational impacts of colonization. Therefore, we plan to stipulate that students must address root causes in their suggested interventions. Engaging in a research project to explore the impacts of this particular teaching and learning strategy on students would be useful to help answer the questions above.

\section{Conclusion}

We agree with Lombardi (2007) who offered that concept mapping is indeed a powerful tool that facilitates and assesses authentic student learning. The concept map assignment was a highly effective tool to help students grasp and apply the PHPM, in addition to advancing their critical

\section{References}

All, A. C. \& Havens, R. L. (1997). Cognitive/concept mapping: A teaching strategy for nursing. Journal of Advanced Nursing, 25, 1210-1219.

All, A. C. \& Huycke, L. I. (2007). Serial concept maps: Tools for concept analysis. Journal of Nursing Education, 46(5), 217-224

All, A. C., Huycke, L. I. \& Fisher, M.J. (2003). Instructional tools for nursing education: concept maps. Nursing Education Perspectives, 24(6), 311317.

Aarons, G. A., Wells, R. S., Zagursky, K., Fettes, D. L., \& Palinkas, L. A. (2009) Implementing evidence-based practice in community mental health agencies: A multiple stakeholder analysis. American Journal of Public Health, 99(11), 2087-2095.

Ausubel, D. (1968). Educational psychology: A cognitive view. New York, NY: Holt, Rinehart, and Winston.

Benach, J., Vives, A., Amable, M., Vanroelen, C., Tarafa, G., \& Muntaner, C. (2014). Precarious employment: Understanding an emerging social determinant of health. Annual Review of Public Health, 35.

Bowleg, L. (2012). The problem with the phrase women and minorities: Intersectionality - an important theoretical framework for public health. American Journal of Public Health, 102(7), 1267-1273.

Burke, J. G., O’Campo, P., Peak, G. L., Gielen, A. C., McDonnell, K. A., \& Trochim, W. M. (2005). An introduction to concept mapping as a participatory public health research method. Qualitative Health Research, 15(10), 1392-1410.

Canadian Nurses Association. (2007). The environment and health: An WITNESS thinking skills. Furthermore, we found that changing the language we used for the determinants of health encouraged students to raise critical questions that recognized the dominant political, economic, and social forces involved. This recognition has helped students to understand how nurses can address systemic inequities rooted in social justice and health equity issues in the populations they chose to explore for the assignment. This innovative teaching and learning approach in community health nursing warrants in-depth evaluation through a structured research project. As we continue to produce various iterations of the concept map assignment, we offer this teaching innovation for other instructors to explore using in their community health nursing theory courses.

Statement of Ethical Permissions: The information provided in this article is the intellectual property of the three listed authors. Permission was obtained from the following Bachelor of Nursing students from Mount Royal University to include their concept map: Jennifer Bosch, Alex Cuncannon, Nichelle Lalonde \& Surabhi Verma. We acknowledge the students' exceptional work!

introduction for nurses. Retrieved from http://www.cnaaiic.ca/CNA/documents/pdf/publications/Environmental Health_2008_e.pdf

Canadian Public Health Association. (2015). Global change and public health: Addressing the ecological determinants of health. Retrieved from https://www.cpha.ca/sites/default/files/assets/policy/edhdiscussion_e.pdf

Castañeda, H., Holmes, S. M., Madrigal, D. S., Young, M. E. D., Beyeler, N., \& Quesada, J. (2015). Immigration as a social determinant of health. Annual Review of Public Health, 36, 375-392.

Chircop, A. 2020.Ecological determinants of health and environmental health inequities. In. LL. Stamler, L, Yiu, A, Dosani, J. Etowa, \& C. van Daalen-Smith, Community health nursing: A Canadian perspective (pp. 489-502). Toronto, ON: Pearson Canada, Inc.

Daley, B. (1996). Concept maps: Linking nursing theory to clinical practice. Journal of Continuing Education in Nursing, 27, 17-27.

Daley, B. J. \& Torre, D. M. (2010). Concept maps in medical education: An analytical literature review. Medical Education, 44, 440-448. doi:10.1111/j.1365-2923.2010.03628.x

Daley, B. J., Morgan, S., \& Black Beman, S. (2016). Concept maps in nursing education: A historical literature review and research directions. Journal of Nursing Education, 55(11), 631-639.

Dosani, A., Etowa, J. \& van Daalen-Smith. (2020). Critical community health nursing: An imperative. In L. L. Stamler, L. Yiu, A. Dosani, J. Etowa, \& C. van Daalen-Smith. Community health nursing: A Canadian perspective (pp. 604-609). Toronto, ON: Pearson Canada Inc. 
Flynn, L. (1999). Population health promotion model. Revised from original model developed by N. Hamilton and T. Bhatti, Health Promotion Development Division, Health Canada, 1996. Winnipeg, MB: Health Canada, Manitoba/Saskatchewan Region.

Garg, A., Sandel, M., Dworkin, P. H., Kahn, R. S., \& Zuckerman, B. (2012). From medical home to health neighborhood: Transforming the medical into a community-based health neighborhood. The Journal of Pediatrics, 160(4), 535-536. doi:10.1016/j.jpeds.2012.01.001

Greenwood, M., de Leeuw, S., Lindsay, N. M. \& Reading, C. (Eds.). (2015). Determinants of Indigenous peoples' health in Canada: Beyond the social ( $2^{\text {nd }} e d$.). Toronto, ON: Canadian Scholars' Press.

Harrison, S., \& Gibbons, C. (2013). Nursing student perceptions of concept maps: From theory to practice. Nursing Education Perspectives, 34(6), 395-399.

Hay, D., Kinchin, I., Lygo-Baker, S. (2008). Making learning visible: the role of concept mapping in higher education. Studies in Higher Education, 33(3), 295-311. doi: 10.1080/0307507080204925

Health Canada (2013). Underlying premises and evidence table. What makes Canadians healthy or unhealthy? Ottawa, ON: Author. Retrieved from https://www.canada.ca/en/public-health/services/healthpromotion/population-health/what-determines-health/what-makescanadians-healthy-unhealthy.html\#evidence

Higgins, B., \& Reid, H. (2017). Enhancing "conceptual teaching/learning" in a concept-based curriculum. Teaching and Learning in Nursing, 12(2), 95 102.

Hinck, S. M., Webb, P, Sims-Giddens, S., Helton, C., Hope, K. L., Utley, R.,... Yarbrough, S., (2006). Student learning with concept mapping of care plans in community-based education. Journal of Professional Nursing, 22(1), 23-29.

Hunter Revell, S. M. (2012). Concept maps and nursing theory: A pedagogical approach. Nurse Educator, 37(3), 131-135.

Kaddoura, M., VanDyke, O., Cheng, B., \& Shea-Foisy, K. (2016). Impact of concept mapping on the development of clinical judgment skills in nursing students. Teaching and Learning in Nursing, 11(3), 101-107.

Lee, W., Chiang, C., Liao, I., Lee, M., Chen, S., \& Liang, T. (2012). The longitudinal effect of concept map teaching on critical thinking of nursing students. Nursing Education Today, 33(10), 1319-1223. doi: 10.1016/j.nedt.2012.06.010

Lombardi, M. (2007). Authentic learning for the $21^{\text {st }}$ century: An overview. Educause Learning Initiative, ELI Paper 1/2007. Retrieved from http://www.lmi.ub.edu/cursos/s21/REPOSITORIO/documents/Lombardi 2007_Authentic_learning.pdf

Marmot, M. G., \& Bell, R. G. (2011). Improving health: Social determinants and personal choice. American Journal of Preventive Medicine, 40(1), S73S77.

Martin, L. S. \& Evans, D. P. (2015). Conflict as a Social Determinant of Health. SM Journal of Public Health and Epidemiology, 1(2), 1008.

Martyn, C. (2004). Politics as a determinant of health. British Medical Journal, 329(7480), 1423-1424.

McGibbon, E. \& Lukeman, S. (2019). Critical social justice: The moral imperative for critical perspectives in nursing discourse. Witness: The Canadian Journal of Critical Nursing Discourse, 1(1), 1-10.

McGibbon, E., Mulaudzi, F. M., Didham, P., Barton, S., \& Sochan, A. (2014) Toward decolonizing nursing: The colonization of nursing and strategies for increasing the counter-narrative. Nursing Inquiry, 21(3), $179-191$.

Mikkonen, J. \& Raphael, D. (2010). Social determinants of health: The Canadian facts. Toronto: York University School of Health Policy and Management. Retrieved from http://thecanadianfacts.org/

Nesbit, J. D. \& Adesope, O. O. (2006). Learning with concept and knowledge maps: A meta-analysis. Review of Educational Research, 76(3), 413-448. doi: 10.3102/00346543076003413

Novack, J. D. \& Gowin, D. B. (1984). Learning how to learn. Cambridge, MA: Cambridge University Press.

Paradies, Y., Ben, J., Denson, N., Elias, A., Priest, N., Pieterse, A., ... \& Gee, G. (2015). Racism as a determinant of health: A systematic review and metaanalysis. PloS one, 10(9), e0138511.

Pearce, N., \& Davey Smith, G. (2003). Is social capital the key to inequalities in health? American Journal of Public Health, 93(1), 122-129.

Phillips, J. C. \& Schofield, R. (2020). Nursing roles, functions, and practice settings. In L. L. Stamler, L. Yiu, A. Dosani, J. Etowa, \& C. van Daalen-Smith. Community health nursing: A Canadian perspective (pp. 35-57). Toronto, ON: Pearson Canada Inc.

Public Health Agency of Canada. (2018). Social determinants of health and health inequalities. Retrieved from https://www.canada.ca/en/publichealth/services/health-promotion/population-health/what-determineshealth.html.

Public Health Agency of Canada (PHAC) (2018). Key health inequities in Canada. Retrieved from https://www.canada.ca/content/dam/phac aspc/documents/services/publications/science-research/key-healthinequalities-canada-nationalportrait-executive-summary/hir-full-reporteng.pdf

Reading, C., \& Wein, F. (2013). Health equity and social determinants of Aboriginal peoples' health. Retrieved from 
The Canadian Journal of Critical Nursing Discourse

See it. Speak it. Write it. Change it.

https://www.ccnsa-nccah.ca/docs/determinants/RPT-HealthInequalitiesReading-Wien-EN.pdf

Ruiz-Primo, M. A. \& Shavelson, R. J. (1996). Problems and issues in the use of concept maps in science assessment. Journal of Research in Science Teaching, 33(6), 569-600.

Schell, S. F., Luke, D. A., Schooley, M. W., Elliott, M. B., Herbers, S. H., Mueller, N. B., \& Bunger, A. C. (2013). Public health program capacity for sustainability: A new framework. Implementation Science, 8(1), 15.

Vaughn, L. M., Jones, J. R., Booth, E., \& Burke, J. G. (2017). Concept mapping methodology and community-engaged research: A perfect pairing. Evaluation and Program Planning, 60, 229-237.
World Health Organization (2008). Commission on the social determinants of health. Closing the gap in a generation: Health equity through action on the social determinants of health. Final report of the commission on social determinants of health. Geneva, $\mathrm{CH}$ : Author.

World Health Organization. (2011). Environmental health. Retrieved from http://www.who.int/topics/environmental_health/en/

Yue, M., Zhang, M., Zhang, C., \& Jin, C. (2017). The effectiveness of concep mapping on development of critical thinking in nursing education: A systematic review and meta-analysis. Nurse Education Today, 52, 87-94 
Appendix

\section{Concept Map Rubric}

Student Name:

\begin{tabular}{|c|c|c|c|}
\hline \multirow[t]{2}{*}{ Criteria } & \multicolumn{3}{|c|}{ Excellent } \\
\hline & A+ & A & A- \\
\hline $\begin{array}{l}\text { 1.Choice of title } \\
\text { question, issue or } \\
\text { concern }\end{array}$ & \multicolumn{3}{|c|}{$\begin{array}{l}\text { Substantial and highly relevant to the population } \\
\text { group. Three key elements integrated appropriately } \\
\text { into a coherent title question. }\end{array}$} \\
\hline $\begin{array}{l}\text { 2. Concept map choice } \\
\text { of themes, concepts, } \\
\text { sub-concepts, and key } \\
\text { words }\end{array}$ & \multicolumn{3}{|c|}{$\begin{array}{l}\text { Work exhibits a comprehensive selection of a } \\
\text { minimum of } 25 \text { items (including concepts and/or, } \\
\text { sub-concepts) Demonstrates a depth of } \\
\text { understanding verified through detail provided. } \\
\text { Work is based on appropriate literature with } \\
\text { appropriate superscript number usage. }\end{array}$} \\
\hline $\begin{array}{l}\text { 3. Demonstration of the } \\
\text { interrelatedness of } \\
\text { concepts, and sub- } \\
\text { concepts though } \\
\text { linkages }\end{array}$ & \multicolumn{3}{|c|}{$\begin{array}{l}\text { Demonstrates sophisticated thinking through } \\
\text { consistent and comprehensive demonstration of } \\
\text { meaningful linkages and interrelatedness of } \\
\text { concepts (and/or sub-concepts). Integration of } \\
\text { relevant research is logical. }\end{array}$} \\
\hline $\begin{array}{l}\text { 4. Use of social } \\
\text { determinants of health }\end{array}$ & \multicolumn{3}{|c|}{$\begin{array}{l}\text { Consistent, comprehensive, and meaningful } \\
\text { linkages made from items (concepts and//or sub- } \\
\text { concepts) to at least } 8 \text { social determinants of } \\
\text { health. All concepts linked appropriately to one or } \\
\text { more determinant of health. Comprehensive } \\
\text { relationship to the question. }\end{array}$} \\
\hline $\begin{array}{l}\text { 5. Use of community } \\
\text { health nursing } \\
\text { interventions, health } \\
\text { promotion action } \\
\text { strategies and levels of } \\
\text { action }\end{array}$ & \multicolumn{3}{|c|}{$\begin{array}{l}\text { The required number of concepts (and/or sub- } \\
\text { concepts) are linked to an appropriate community } \\
\text { health nursing intervention and appropriate level of } \\
\text { action. All of the community health nursing } \\
\text { interventions are categorized appropriately in } \\
\text { terms of the } 5 \text { broad action strategy categories in } \\
\text { the PHPM. }\end{array}$} \\
\hline $\begin{array}{l}\text { 6. Creativity, } \\
\text { Organization, Clarity, } \\
\text { and Appearance of } \\
\text { Concept Map }\end{array}$ & \multicolumn{3}{|c|}{$\begin{array}{l}\text { Highly creative, easy to read, all linkages are clear } \\
\text { and easy to follow, formatted correctly. Organized, } \\
\text { neat and tidy. }\end{array}$} \\
\hline 7. Discussion paper & \multicolumn{3}{|c|}{$\begin{array}{l}\text { Concise, thoughtful, clear description and } \\
\text { discussion at a level that shows depth of }\end{array}$} \\
\hline
\end{tabular}

Assignment Grade:

\begin{tabular}{|c|c|c|c|c|c|c|c|}
\hline \multicolumn{3}{|c|}{ Above Average } & \multicolumn{2}{|c|}{ Satisfactory } & \multicolumn{3}{|c|}{ Unsatisfactory } \\
\hline B+ & B & B- & $\mathrm{C}+$ & C & C- & D+/D & $\mathbf{F}$ \\
\hline \multicolumn{3}{|c|}{$\begin{array}{l}\text { Relevant to the population chosen. Three key } \\
\text { elements integrated appropriately into a } \\
\text { sentence. }\end{array}$} & \multicolumn{2}{|c|}{$\begin{array}{l}\text { Demonstrates some thought but was not a } \\
\text { good fit with the population group and/or } \\
\text { omitted one of the three required elements. } \\
\text { Awkward wording of title question. }\end{array}$} & \multicolumn{3}{|c|}{$\begin{array}{l}\text { Superficial, not applicable or inappropriate to } \\
\text { the population group. Omitted two or all of the } \\
\text { three required elements. Title presented as an } \\
\text { incoherent sentence. }\end{array}$} \\
\hline \multicolumn{3}{|c|}{$\begin{array}{l}\text { Work exhibits a good selection of a minimum } \\
\text { of } 25 \text { items (concepts and/or sub-concepts). } \\
\text { Demonstrates a good understanding verified } \\
\text { through detail provided. Work is based on } \\
\text { literature with appropriate superscript number } \\
\text { usage. }\end{array}$} & \multicolumn{2}{|c|}{$\begin{array}{l}\text { Exhibits a choice of items (concepts } \\
\text { and//or sub-concepts). Shows basic } \\
\text { integration and understanding of the } \\
\text { question/issue/concern. Concepts require } \\
\text { more detail. Includes a minimum of } 15 \\
\text { concept items. Some inappropriate or } \\
\text { missing references. }\end{array}$} & \multicolumn{3}{|c|}{$\begin{array}{l}\text { Unable to demonstrate coherent selection of } \\
\text { concepts or developmental thought. Minimal or } \\
\text { no explanation of concepts. Misunderstanding } \\
\text { or omission of information. Less than } 15 \text { items } \\
\text { profiled (concepts and/or sub-concepts). Less } \\
\text { than half of concepts linked to literature. }\end{array}$} \\
\hline \multicolumn{3}{|c|}{$\begin{array}{l}\text { Demonstrates high-level thinking through } \\
\text { demonstration of meaningful linkages and } \\
\text { interrelatedness of concepts (and/or sub- } \\
\text { concepts). Integration of relevant research is } \\
\text { logical. }\end{array}$} & \multicolumn{2}{|c|}{$\begin{array}{l}\text { Demonstrates some literature review and } \\
\text { thought in creating meaningful linkages } \\
\text { but also has some indicators of irrelevant } \\
\text { or erroneous linkages. May be missing } \\
\text { some relevant items. }\end{array}$} & \multicolumn{3}{|c|}{$\begin{array}{l}\text { Demonstration of linkages is superficial, } \\
\text { irrelevant or erroneous in the connections made. } \\
\text { Relevant items are missing. }\end{array}$} \\
\hline \multicolumn{3}{|c|}{$\begin{array}{l}\text { More than half of the required number of } \\
\text { concepts (and/or sub-concepts) are linked to at } \\
\text { least } 6 \text { social determinants of health in a } \\
\text { meaningful and appropriate way. Strong } \\
\text { content that relates directly to the question } \\
\text { posed }\end{array}$} & \multicolumn{2}{|c|}{$\begin{array}{l}\text { Half of the required number of concepts } \\
\text { (and/or sub-concepts) are linked to at least } \\
4 \text { social determinants of health in a } \\
\text { meaningful and appropriate way. } \\
\text { Adequate demonstration of link to } \\
\text { question posed. }\end{array}$} & \multicolumn{3}{|c|}{$\begin{array}{l}\text { Less than half of the required number of } \\
\text { concepts (and/or sub-concepts) are linked to at } \\
\text { least } 3 \text { determinants of health. Most linkages are } \\
\text { unclear or inappropriate. Unrelated application } \\
\text { to the question. }\end{array}$} \\
\hline \multicolumn{3}{|c|}{$\begin{array}{l}\text { More than half of the required number of } \\
\text { concepts relate to an appropriate community } \\
\text { health nursing intervention and appropriate } \\
\text { level of action. Most of the community health } \\
\text { nursing interventions are categorized } \\
\text { appropriately in terms of the } 5 \text { broad action } \\
\text { strategy categories in the PHPM. }\end{array}$} & \multicolumn{2}{|c|}{$\begin{array}{l}\text { Half of the required number of concepts } \\
\text { (and/or sub-concepts) are linked to an } \\
\text { appropriate community health nursing } \\
\text { intervention and appropriate level of } \\
\text { action. Half of the community health } \\
\text { nursing interventions are categorized } \\
\text { appropriately in terms of the } 5 \text { broad } \\
\text { action strategy categories in the PHPM. }\end{array}$} & \multicolumn{3}{|c|}{$\begin{array}{l}\text { Less than half the required number of items } \\
\text { (concepts and/or sub-concepts) are linked to an } \\
\text { appropriate community health nursing } \\
\text { intervention and appropriate level of action. } \\
\text { Health promotion interventions are NOT } \\
\text { categorized appropriately in terms of the } 5 \\
\text { broad action strategy categories in the PHPM. }\end{array}$} \\
\hline \multicolumn{3}{|c|}{$\begin{array}{l}\text { Somewhat creative, easy to read, most } \\
\text { linkages are clear and easy to follow, } \\
\text { formatted correctly. Organized, neat and tidy. }\end{array}$} & \multicolumn{2}{|c|}{$\begin{array}{l}\text { Minimally creative, easy to read, some } \\
\text { linkages are clear and some difficult to } \\
\text { follow, formatted correctly. Some areas of } \\
\text { the map appear disorganized. }\end{array}$} & \multicolumn{3}{|c|}{$\begin{array}{l}\text { No creativity demonstrated, difficult to read, } \\
\text { messy, disorganized; formatted incorrectly. } \\
\text { Links missing or inappropriately connected. }\end{array}$} \\
\hline \multicolumn{3}{|c|}{$\begin{array}{l}\text { Clear description and discussion at a level that } \\
\text { shows good understanding of the chosen item }\end{array}$} & \multicolumn{2}{|c|}{$\begin{array}{l}\text { Discussion at a level that shows basic } \\
\text { understanding of the chosen item (concept }\end{array}$} & \multicolumn{3}{|c|}{$\begin{array}{l}\text { Discussion at a level that shows poor } \\
\text { understanding of the chosen item (concept or }\end{array}$} \\
\hline
\end{tabular}

VOL 1, ISSUE 2 


\begin{tabular}{|c|c|c|c|c|}
\hline & $\begin{array}{l}\text { understanding of the chosen item (concept or sub- } \\
\text { concept) as it relates to a determinant of health, } \\
\text { community health nursing intervention, action } \\
\text { strategy, level of action, evidence-based research } \\
\text { and student's values and assumptions. }\end{array}$ & $\begin{array}{l}\text { (concept or sub-concept) as it relates to a } \\
\text { determinant of health, community health } \\
\text { nursing intervention, action strategy, level of } \\
\text { action, evidence-based research and student's } \\
\text { values and assumptions. }\end{array}$ & $\begin{array}{l}\text { or sub-concept) as it relates to a } \\
\text { determinant of health, community health } \\
\text { nursing intervention, action strategy, level } \\
\text { of action, evidence-based research and } \\
\text { student's values and assumptions. Some } \\
\text { erroneous conclusions drawn. }\end{array}$ & $\begin{array}{l}\text { sub-concept)as it relates to a determinant of } \\
\text { health, community health nursing intervention, } \\
\text { action strategy, level of action, evidence-based } \\
\text { research and student's values and assumptions. } \\
\text { Many erroneous conclusions drawn or } \\
\text { components missing. }\end{array}$ \\
\hline 8. APA and References & $\begin{array}{l}\text { Discussion paper follows APA format. A } \\
\text { minimum of } 15 \text { highly relevant and current } \\
\text { research articles are included in the concept map; } \\
\text { no APA errors in text or reference list. }\end{array}$ & $\begin{array}{l}\text { Discussion paper follows APA format with } \\
\text { few errors. Most of references used in the } \\
\text { concept map are research articles; most } \\
\text { elements of APA format/style are present. }\end{array}$ & $\begin{array}{l}\text { Discussion paper has a number of APA } \\
\text { errors. About half of references used in } \\
\text { concept map are research articles; other } \\
\text { references are from inappropriate or } \\
\text { irrelevant literature and websites; about } \\
\text { half of the elements of APA format/style } \\
\text { are present. }\end{array}$ & $\begin{array}{l}\text { Multiple APA errors in discussion paper. Less } \\
\text { than half of references used in concept map are } \\
\text { inappropriate or irrelevant; less than half of the } \\
\text { elements of APA format/style are present; paper } \\
\text { over maximum limit. }\end{array}$ \\
\hline 9. Comments & \multicolumn{4}{|c|}{ Please note: Written comments are included on the concept map and/or paper. } \\
\hline
\end{tabular}

